\title{
ULTRASTRUCTURE OF THE RAT MAMMARY GLAND AFTER LACTOGENESIS INDUCED BY PERPHENAZINE
}

\author{
T. T. MILlER, R. T. GHATTERTON, JR AND J. A. HARRIS
}

Department of Obstetrics and Gynecology, The Abraham Lincoln School of Medicine, University of Illinois at the Medical Center, Chicago, Illinois 60612, U.S.A.

\section{(Received 6th February 1974)}

Summary. The ultrastructural response of the rat mammary gland was studied in normal oestrous rats given $0 \cdot 0,2 \cdot 5,5 \cdot 0$ or $10.0 \mathrm{mg}$ perphenazine $/ \mathrm{kg}$ body weight daily for 5 days starting $12 \mathrm{hr}$ after ovulation. Growth of the parenchymal tissue was largely limited to alveolar development. Tissue from controls receiving only injections of the $0.03 \mathrm{~N}-\mathrm{HCl}$ vehicle was similar to that from rats at 7 days' gestation, the earliest stage of pregnancy studied. Protein granules appeared in the Golgi complexes in rats given the $2.5 \mathrm{mg} / \mathrm{kg}$ dose and the occurrence increased with increasing dose levels, but these granules did not appear in the lumina until the dose reached $5.0 \mathrm{mg} / \mathrm{kg}$. Large lipid droplets appeared in the cytoplasm in rats given the $5.0 \mathrm{mg} / \mathrm{kg}$ dose or more, but were not found in the lumina except at the highest dose.

Despite the presence of abundant protein and lipid accumulations in the cytoplasm and lumina in mammary tissue of rats given the $10 \cdot 0$ $\mathrm{mg} / \mathrm{kg}$ dose and the abundance of free ribosomes in the parenchymal cells, the rough endoplasmic reticulum was grossly underdeveloped as compared with mammary glands removed from pregnant rats 2 days before parturition. Evidence is presented from these and collateral studies to suggest that progesterone levels, elevated by the perphenazine treatment, are responsible for inhibition of rough endoplasmic reticulum development and, thus, the capacity for both protein and lipid biosynthesis.

\section{INTRODUGTION}

Perphenazine administration has been shown to induce secretion of prolactin (Ben-David, Danon, Benveniste, Weller \& Weller, 1971; Blackwell, Vale, Rivier \& Guillemin, 1973) and to result in elevated serum levels of progesterone and corticosterone (Ghatterton, Ghien \& Ward, 1974). Serum oestrogen (Chatterton et al., 1974) and ovulation (Velardo, 1958) are suppressed by perphenazine administration, but growth hormone secretion is apparently unaffected (Tyson \& Friesen, 1973; MacLeod, Fontham \& Lehmeyer, 1970). Ben-David (1968a) has clearly demonstrated by light microscopy the mammotrophic effect of perphenazine when administered to the intact rat. On the other hand, no galactopoietic effect has been observed (Weller, Shani, Givant \& Sulman, 
1972). In order to evaluate more completely the morphological response of the mammary glands to the hormonal conditions induced by phenothiazine drugs, the ultrastructural features of the tissue were described in animals receiving different doses of perphenazine.

\section{MATERIALS AND METHODS}

Rats from Hormone Assay Laboratories (Chicago) were housed in an airconditioned room with controlled lighting cycles of $14 \mathrm{hr}$ light $/ 10 \mathrm{hr}$ dark. Vaginal smears were taken daily for at least two complete oestrous cycles before selection of the animals for the experiment. Rats were randomly assigned to one of four groups for injection with $0 \cdot 0,2 \cdot 5,5 \cdot 0$ or $10.0 \mathrm{mg}$ perphenazine $/ \mathrm{kg}$ body weight. Perphenazine or the $0.03 \mathrm{~N}-\mathrm{HCl}$ diluent was injected subcutaneously daily for 5 days, starting on the day of oestrus. Body weight was measured at the beginning and at the end of the treatment period. Vaginal smears were continued daily until the rats were killed. Mammary glands were removed on Day 6. Part of the mammary tissue was fixed for histological and part for electron microscopic study. Sections of the mammary tissue were evaluated by light microscopy for the degree of development according to the mammotrophic index (MTI) of Ben-David (1968a); Grades I to II represent the degrees of development in the normal gland, III, IV and V represent increasing alveolar development and onset of milk secretion, and IV represents the fully lactating condition.

Tissues were fixed in buffered $4 \%$ formaldehyde for light microscopy. Paraffin wax-embedded tissue was sectioned and stained with haematoxylin and eosin. For electron microscopy, 0.5 to $1.0 \mathrm{~mm}$ specimens of tissue from each of the rats listed in Table 1 were fixed in a solution containing $1.5 \%$ paraformaldehyde, $1.5 \%$ acrolein and $3 \%$ glutaraldehyde for $1 \mathrm{hr}$. The tissue was then rinsed three times in $15 \%$ sucrose. It was then stained with $1 \%$ osmic acid for $1 \mathrm{hr}$. Each of the above solutions was buffered in $0.05 \mathrm{M}$-phosphate, $\mathrm{pH} \mathrm{7.5.} \mathrm{After} \mathrm{dehydration} \mathrm{in} \mathrm{alcohol,} \mathrm{the} \mathrm{tissue} \mathrm{was} \mathrm{embedded} \mathrm{in} \mathrm{Araldite.}$ After slow polymerization, thick $(2 \mu \mathrm{m})$ sections were prepared on a PorterBlum MT-1 ultramicrotome for phase-contrast microscopy. From each rat, a minimum of 300 representative thin sections $(600 \AA)$ of mammary gland tissue were stained with lead citrate, and were examined with a Zeiss EM-9A electron microscope.

\section{RESULTS}

Daily treatment of $225 \mathrm{-g}$ rats with $2.5 \mathrm{mg}$ perphenazine $/ \mathrm{kg}$ body weight for 5 days resulted in a $3 \pm 10$ (S.D.) $\%$ loss in body weight. The $5 \mathrm{mg} / \mathrm{kg}$ and $10 \mathrm{mg} / \mathrm{kg}$ doses resulted in losses of $19 \pm 6$ (S.D.) and $20 \pm 4$ (S.D.) \%, respectively. No animals died during treatment. Control rats gained an average of $3 \pm 2$ (S.D.) $\%$ body weight and exhibited vaginal cornification on the 5 th day of injection of the vehicle. Vaginal smears of all rats treated with perphenazine contained only leucocytes. Corpora haemorrhagica were present in control rats on the day of autopsy, but corpora lutea were found in ovaries of all 
perphenazine-treated rats, indicating that a state of pseudopregnancy had been maintained.

Grossly, mammary glands of control and 7-day-pregnant rats were difficult to identify, but a dose-related degree of hyperaemia and decreased content of fat characterized the mammary glands of rats treated with perphenazine.

Sections of the tissue were examined by light microscopy. Some branching of the ductal system and alveolar development occurred with the $2.5 \mathrm{mg} / \mathrm{kg}$ and greater doses but extensive lobule formation did not occur. Changes due to the treatment were restricted primarily to differentiation of ductule and alveolar cells from a resting to a secretory type. The MTI grade assigned to tissue from each animal is presented in Table 1 . There was clearly an increase in the index between controls and rats receiving the lowest dose. No distinction could be

Table 1. Mammotrophic response of rat mammary glands to perphenazine

\begin{tabular}{c|c|c}
\hline $\begin{array}{c}\text { Dose of perphenazine* } \\
(\mathrm{mg} / \mathrm{kg} \text { body } w \mathrm{w})\end{array}$ & Animal no. & MTI Grades \\
\hline 0 & 4 & II \\
& 23 & I \\
& 21 & II \\
2.5 & 3 & I \\
& 7 & IV \\
& 1 & IV \\
5.0 & 10 & III \\
& 11 & III \\
& 18 & IV \\
10.0 & 8 & III \\
& 13 & II \\
& 15 & IV \\
& 19 & VI \\
& 2 & III \\
& 17 & IV \\
& 6 & IV \\
\hline
\end{tabular}

MTI, mammotrophic index (Ben-David, 1968a). For grading, see text.

* Subcutaneous injections of perphenazine were given daily for 5 days.

made between mammary tissue from rats on the lowest and intermediate doses, but the response was clearly greater on the average in animals receiving the highest dose.

Electron microscopy revealed further distinctions among the treatment groups (PI. 2, Figs 2 and 3; Pl. 3, Fig. 4; Pl. 4, Fig. 5) and permitted more accurate comparisons with normal development (Pl. 1, Fig. 1; Pl. 4, Fig. 6). The nuclear form, size, and chromatin distribution did not vary among the treatment groups. Prominent nucleoli were uniformly present. Mitosis was rarely observed. Tissue from control, non-pregnant rats was similar in all respects to that obtained from rats at 7 days' gestation. The apices of ductule and alveolar cells were virtually in contact; when fluid was present in the 
lumina, it was agranular. At the lowest dose of perphenazine, somewhat asynchronous development occurred but even when the lumina were more distended, the fluid was agranular. An increasing number of cross-sections of ductules and alveoli in the groups receiving $5.0 \mathrm{mg} / \mathrm{kg}$ had lumina with electrondense protein granules, 60 to $200 \mathrm{~nm}$ in diameter, but lipid droplets were seldom seen. Similar lumina in the group receiving $10 \mathrm{mg} / \mathrm{kg}$ were consistently larger and contained both protein granules and lipid droplets.

The presence or absence of protein and lipid in the lumina was not a reflection of the presence of these substances in the cytoplasm of glandular cells. Although the control group had none, single protein granules appeared in Golgi vesicles in cells of the group receiving $2.5 \mathrm{mg} / \mathrm{kg}$. In the groups receiving 5.0 and $10.0 \mathrm{mg} / \mathrm{kg}$, the number of such vesicles increased and cells of many alveoli also contained stasis vacuoles composed of aggregates of protein granules. Likewise, lipid droplets were abundant in the cytoplasm of most cells of the group receiving $5.0 \mathrm{mg} / \mathrm{kg}$, but rarely appeared in the alveolar lumina.

The volume of cytoplasm increased with increasing doses of perphenazine as did the volume of inclusions from the control to the $5.0 \mathrm{mg} / \mathrm{kg}$ dose, particu-

\section{EXPLANATION OF PLATES}

\section{PLATE 1}

Fig. 1. Mammary gland alveolus from a rat at 7 days' gestation. A small lumen is present (L), which is devoid of protein granules or lipid droplets. The cytoplasm of parenchymal cells is densely granular due to free ribosomes, and some RER (E) is present. Golgi membranes $(G)$ are extensive, but unexpanded. $\times 10,425$.

\section{PLATE 2}

Fig. 2. Mammary gland parenchymal cells from a non-pregnant control rat receiving vehicle injections $(0.03 \mathrm{~N}-\mathrm{HCl})$ for 5 days only. The unexpanded lumen (L) of a duct is shown devoid of fluid. Development is otherwise similar to that present in the 7 day pregnant rat. $\times 4400$.

FIG. 3. Mammary gland alveolus from a rat receiving $2.5 \mathrm{mg}$ perphenazine $/ \mathrm{kg}$. A rarely observed cell in mitosis is present adjacent to the lumen (L) of the alveolus. Small electron-dense lipid droplets $(F)$ were observed in some cells. The development of RER was little affected by the treatment. The Golgi apparatus, not well visualized in this section, occasionally contained protein granules, but the lumen remained agranular. $\times 4400$.

\section{PLATE 3}

FIG. 4. Mammary gland parenchymal cells from a rat receiving $5.0 \mathrm{mg}$ perphenazine $/ \mathrm{kg}$. The lumen (L) contained protein granules; the Golgi apparatus was somewhat expanded and vesicles containing protein secretion $(\mathbf{P})$ were observed. In addition, this cell contains several stasis vacuoles (S) containing compacted protein granules. Such stasis vacuoles occurred in some alveolar cells of rats given this and the $10.0 \mathrm{mg} / \mathrm{kg}$ dose. Less osmiophilic lipid droplets (F) (typical of the lactating gland) and frequently of larger size than those in glands of rats given the $2.5 \mathrm{mg} / \mathrm{kg}$ dose were observed in all parenchymal cells, although none appeared in the lumen. The RER is not appreciably better developed than that seen in the control. $\times 10,425$.

\section{PLATE 4}

FIG. 5. Mammary gland parenchymal cells from a rat receiving $10.0 \mathrm{mg}$ perphenazine $/ \mathrm{kg}$. The lumen contains both protein granules and lipid droplets. Golgi vesicles containing single protein granules $(P)$ in a relatively clear fluid are abundant, although the particular cells shown have no stasis vacuoles. Large lipid droplets $(F)$ are seen in the cells. The RER (E) is increased somewhat over that seen with lower doses of perphenazine. $\times 7400$.

FIG. 6. Mammary gland parenchymal cells from a rat on the 22nd day of pregnancy. Both lipid droplets and protein granules are present in a greatly expanded lumen; the cells appear compressed. Note the large lipid droplets partly extruded and the extensive parallel sacs of RER (E). $\times 7400$. 
PI.ATE 1

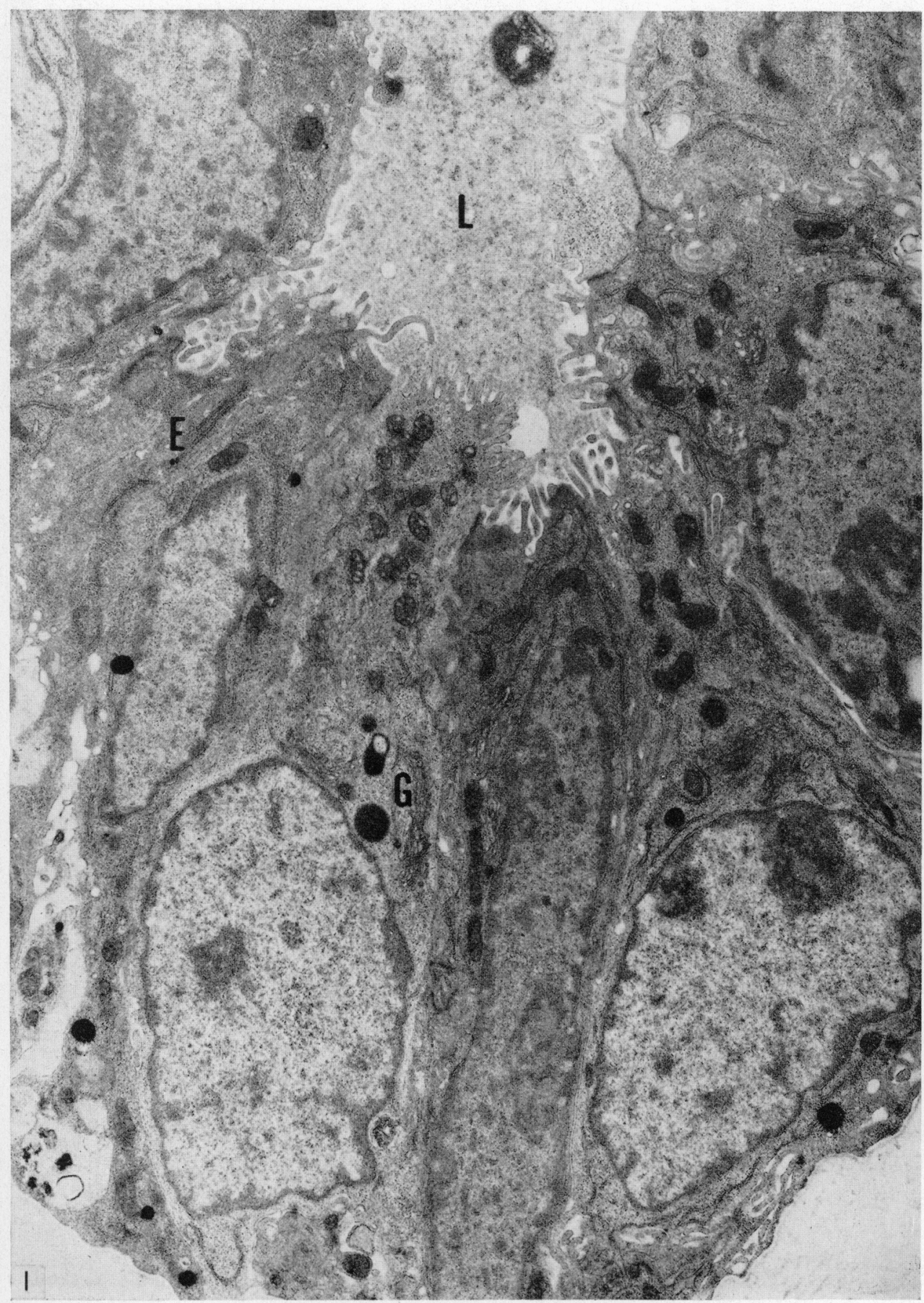

(ficing p. 146) 


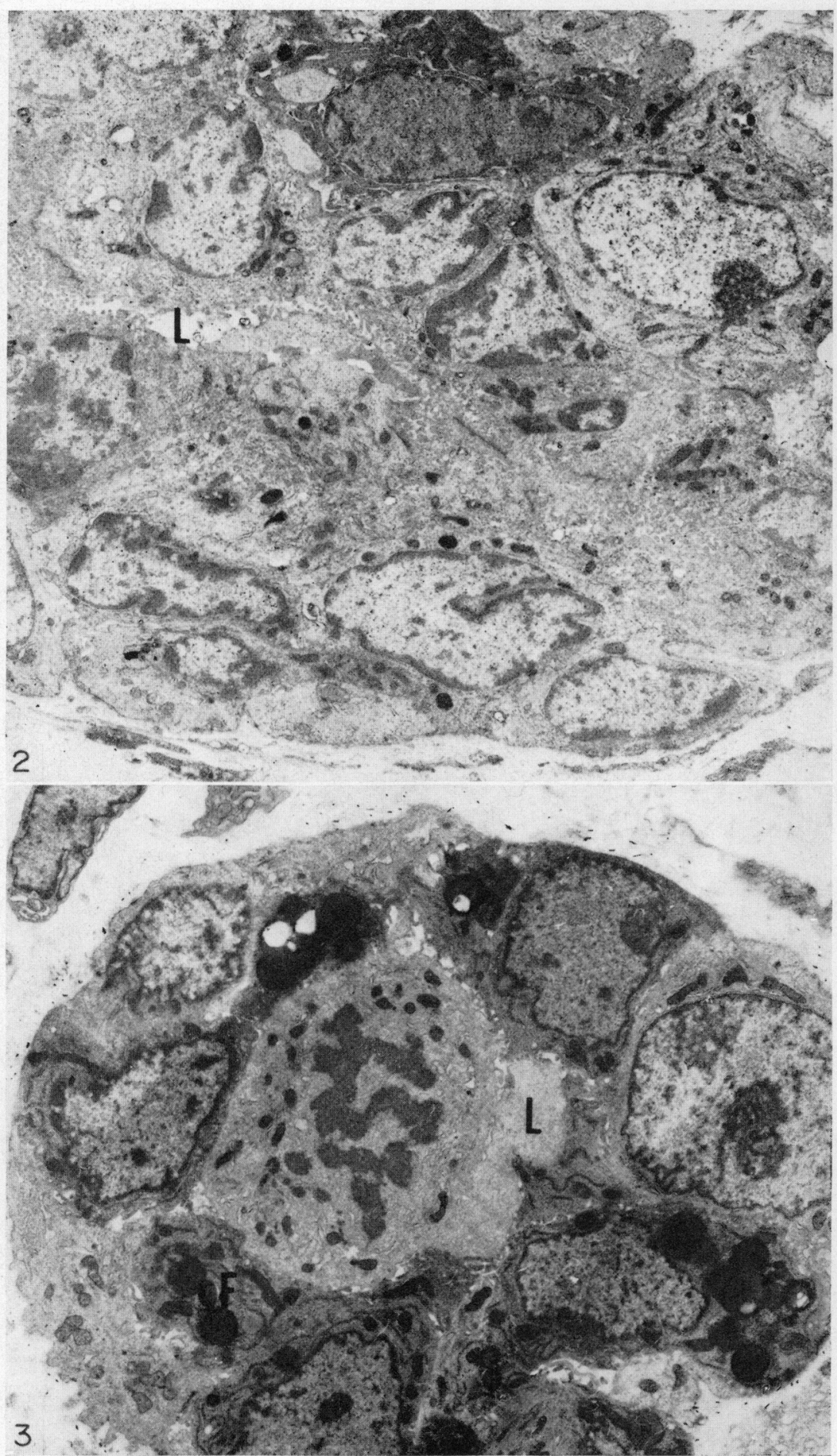


PLATE 3

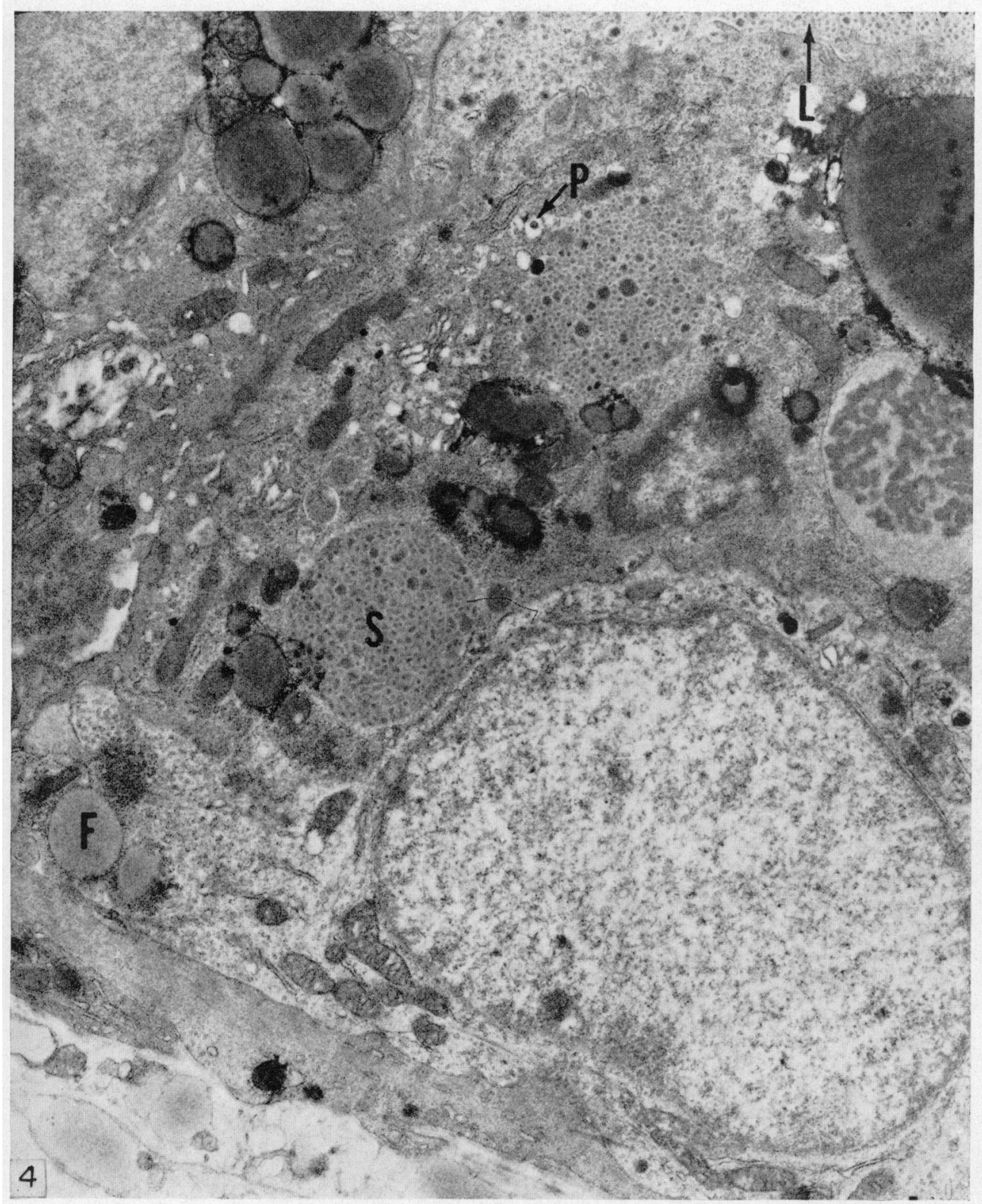




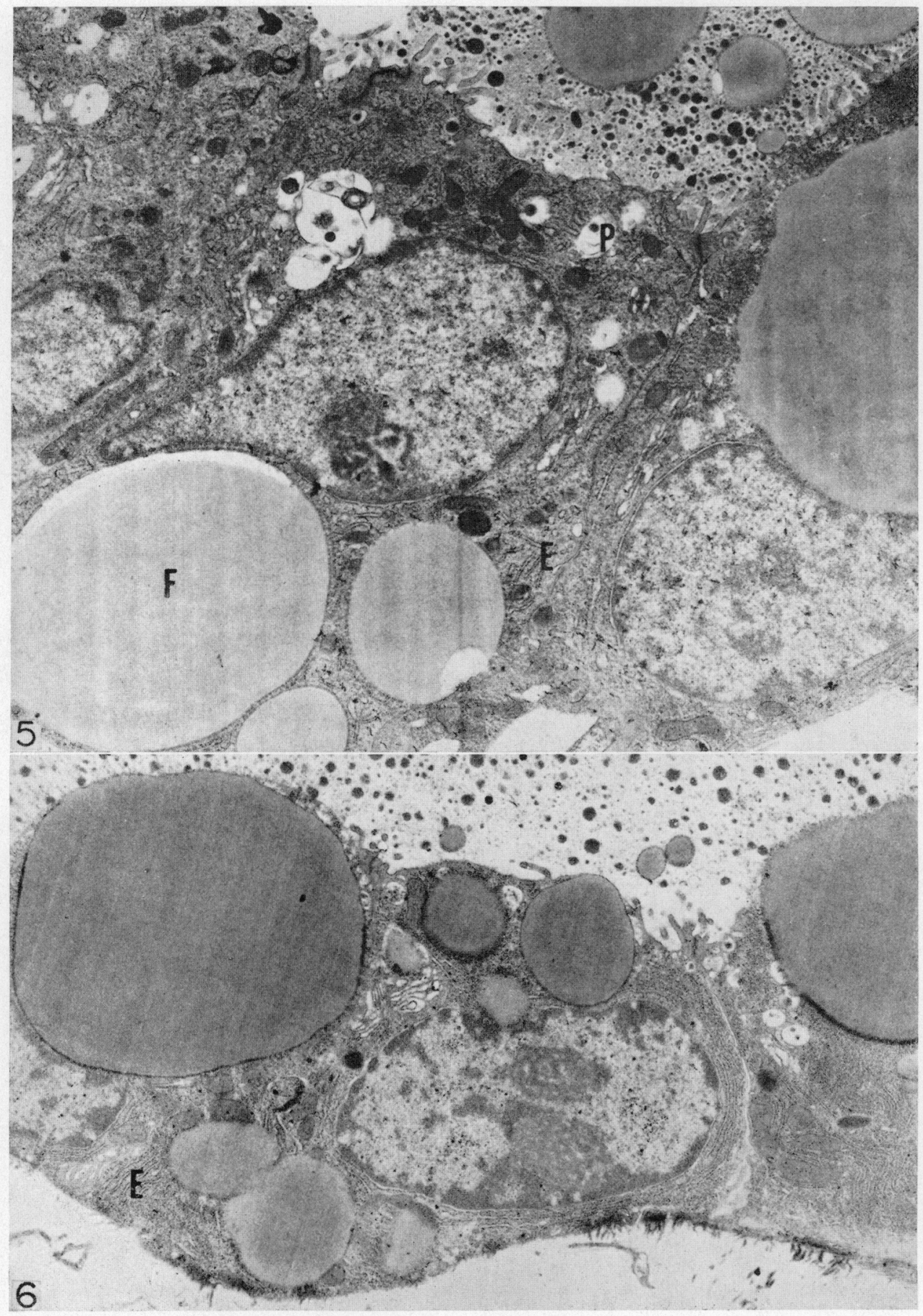


larly in the more highly differentiated alveoli. At the $10.0 \mathrm{mg} / \mathrm{kg}$ dose, an increase in the number of differentiated alveoli was observed. The mitochondria did not change appreciably, but the ribosomes that were abundant in cells of all groups became increasingly membrane-bound, forming vesicular rough endoplasmic reticulum (RER) in the group receiving $2.5 \mathrm{mg} / \mathrm{kg}$, and an increasing number of flattened parallel sacs were observed with increasing doses of perphenazine. Even so, the degree of RER development in the rats receiving $10 \mathrm{mg} / \mathrm{kg}$ was much lower than that present in mammary tissue from rats 0 to 2 days before parturition (Pl. 4, Fig. 6), and represents the primary difference in the pharmacologically induced and normally developed parenchymal cells.

\section{DISCUSSION}

Perphenazine, in the doses used, acts in the intact rat to increase dramatically the circulating levels of prolactin (Ben-David et al., 1971; Blackwell et al., 1973) to levels greater than that reached at any time during pregnancy (Linkie \& Niswender, 1972). The treatment also results in elevated progesterone levels, but the lowest dose $(2.5 \mathrm{mg} / \mathrm{kg})$ apparently stimulated the ovaries maximally; serum progesterone was similar, about $60 \mathrm{ng} / \mathrm{ml}$, after 5 days of treatment at each dose level studied (Chatterton, Miller \& Harris, 1973). The elevation in oestradiol-17 $\beta$ levels associated with pro-oestrus (Chatterton et al., 1974) was abolished due to the maintenance of a pseudopregnant state (Ben-David, 1968b) and inhibition of ovulation (Velardo, 1958).

Suppression of serum oestrogen in rats in which treatment was begun on the day of oestrus (approximately $12 \mathrm{hr}$ after ovulation) would restrict duct growth (Lyons, Li \& Johnson, 1958) and is undoubtedly responsible for the limited degree of lobulo-alveolar development observed. Hormonal requirements for alveolar differentiation (Lyons et al., 1958) are met by the treatment, but secretion may be inhibited by continued production of progesterone (Turkington \& Hill, 1969).

Since the prolactin response to perphenazine increases with increasing doses of the drug and the progesterone levels were similar at all three doses, the effects of prolactin can be evaluated independently of changes in progesterone. Ultrastructural studies provide information on the presence of lipid and protein components of milk, on the release of these components from the parenchymal cells, and on the presence of intracellular structures that form these products. Both the lipid (Stein \& Stein, 1967; Wellings, DeOme \& Pitelka, 1960) and the protein (Wellings \& Philp, 1964) of milk have been shown to be synthesized in the RER. Furthermore, Denamur (1969) has shown that free ribosomes in the mammary cell do not have appreciable biosynthetic activity; only after they become membrane-bound, forming the RER, is the capacity for protein synthesis achieved. Based on this information, the primary consideration in assessing biosynthetic capacity of the cells is the development of the RER.

Development of the RER increased progressively with the dose of perphenazine administered but at the highest dose it was much smaller than that observed by Fiddler, Birkinshaw \& Falconer (1971) or Tobon, Josimovich \& 
Salazar (1972) after intraductal prolactin injections in the pseudopregnant rabbit. Mills \& Topper (1970) found that the presence of cortisol was required in addition to insulin for development of the RER in explanted mouse mammary tissue and that prolactin promoted the secretory process leading to casein biosynthesis. According to Wellings \& Nandi (1968), aldosterone or corticosterone are equally as effective as cortisol in satisfying the adrenocorticosteroid requirement for differentiation of mammary tissue in vitro. A deficiency in adrenocortical hormones cannot explain the lesser development of RER in rats receiving perphenazine, since a twofold elevation of corticosterone has been found in rats receiving $5.0 \mathrm{mg}$ perphenazine $/ \mathrm{kg}$ body weight/day (Chatterton et al., 1974). Since perphenazine injections result in elevations in both systemic prolactin and progesterone, the increase in progesterone may account for the fact that the treatment was less effective than intraductal injections of prolactin. Progesterone has been shown to compete for adrenocorticosteroid receptors in other tissues and is implicated here as interfering with the requirement of adrenal steroids for induction of the RER. This suggestion is consistent with the observation that induction of milk secretion is readily inhibited by progesterone, but established lactation is not (Walker \& Matthews, 1949). Once the RER is developed, progesterone cannot inhibit the biosynthetic processes.

Transport processes in this tissue do not appear to be abnormal. Protein secretion normally takes place earlier in development of the alveolus than does lipid secretion (Hollmann, 1969). Under conditions where milk is not ejected from the alveoli, stasis vacuoles containing protein granules normally accumulate within the epithelial cytoplasm (Hollmann \& Verly, 1967; Richards \& Benson, 1971). Although sufficient biosynthetic potential was present in rats receiving the $10.0 \mathrm{mg} / \mathrm{kg}$ dose to produce observable amounts of protein and lipid in the cytoplasm and lumina of the alveoli within the 5 days of treatment, the rate of biosynthesis must be severely limited when compared with that of the pregnant rat 1 day before parturition.

\section{ACKNOWLEDGMENTS}

The authors thank Dr Ralph M. Wynn for his advice in the course of this study and for his critical review of the manuscript. We are indebted to Dr P. L. Pearlman of the Schering Corporation, Bloomfield, New Jersey, for perphenazine. The study was supported by a grant from the USPHS, NIH, HD-06419.

\section{REFERENCES}

BEN-DAvid, M. (1968a) Mechanism of induction of mammary differentiation in Sprague-Dawley female rats by perphenazine. Endocrinology, 83, 1217.

Ben-David, M. (1968b) Role of the ovaries in perphenazine-induced lactation. 7. Endocr. 41, 377.

Ben-David, M., Danon, M., Benveniste, R., Weller, C. P. \& Weller, F. G. (1971) Results of radioimmunoassays of rat pituitary and serum prolactin after adrenalectomy and perphenazine treatment in rats. F. Endocr. 50, 599.

Blackwell, R., Vale, W., Rivier, C. \& Guillemin, R. (1973) Effect of perphenazine on the secretion of prolactin in vivo and in vitro. Proc. Soc. exp. Biol. Med. 142, 68.

Chatterton, R. T., JR, Ghien, J. \& Ward, D. A. (1974) Effect of perphenazine treatment of rats on ovarian serum and adrenal steroids. Proc. Soc. exp. Biol. Med. 145, 874. 
Chatterton, R. T., JR, Miller, T. T. \& HARris, J. (1973) Effect of perphenazine on plasma progesterone and on ultrastructural development of the rat mammary gland. Endocrinology, 90, A-203.

Denamur, T. (1969) Changes in the ribonucleic acids of mammary cells at lactogenesis. In Lactogenesis: The Initiation of Milk Secretion at Parturition, p. 53. Eds. M. Reynolds and S. J. Folley. University of Pennsylvania Press, Philadelphia.

Fiddler, T. J., Birkinshaw, M. \& Falconer, I. R. (1971) Effects of intraductal prolactin on some aspects of the ultrastructure and biochemistry of mammary tissue in the pseudopregnant rabbit. 7. Endocr. 49, 459.

HoLlmanN, K. H. (1969) Quantitative electron microscopy of subcellular organization in mammary cells before and after parturition. In Lactogenesis: The Initiation of Milk Secretion at Parturition, p. 27. Eds. M. Reynolds and S. J. Folley. University of Pennsylvania Press, Philadelphia.

HollmanN, K. H. \& VerLy, J. M. (1967) La régression de la glande mammaire à l'arrêt de la lactation. II. Etude au microscope électronique. Z. Zellforsch. mikrosk. Anat. 82, 222.

LiNkre, D. M. \& Niswender, G. D. (1972) Serum levels of prolactin, luteinizing hormone, and follicle stimulating hormone during pregnancy in the rat. Endocrinology, 90, 632.

Lyons, W. R., LI, C. H. \& Johnson, R. E. (1958) The hormonal control of mammary growth and lactation. Recent Prog. Horm. Res. 14, 219.

MacLeod, R. M., Fontham, E. H. \& Lehmeyer, J. E. (1970) Prolactin and growth hormone production as influenced by catecholamines and agents that affect brain catecholamines. Neuroendocrinology, 6, 283.

MrLLs, E. S. \& TOPPER, Y. J. (1970) Some ultrastructural effects of insulin, hydrocortisone, and prolactin on mammary gland explants. 7. Cell Biol. 44, 310.

Richards, R. C. \& Benson, G. K. (1971) Ultrastructural changes accompanying involution of the mammary gland in the albino rat. F. Endocr. 51, 127.

Stein, O. \& STEIN, Y. (1967) Lipid synthesis, intracellular transport, and secretion. II. Electronmicroscopic autoradiographic study of the mouse lactating mammary gland. F. Cell Biol. 34, 251.

Tobon, H., Josimovich, J. B. \& SALAzAR, H. (1972) The ultrastructure of the mammary gland during prolactin-induced lactogenesis in the rabbit. Endocrinology, 90, 1569.

TuRkington, R. W. \& Hill, R. L. (1969) Lactose synthetase: progesterone inhibition of the induction of $\alpha$-lactalbumin. Science, $\mathcal{N} . Y .163,1458$.

Tyson, J. E. \& FrIeSEN, H. G. (1973) Factors influencing the secretion of human prolactin and growth hormone in menstrual and gestational women. Am. F. Obstet. Gynec. 116, 377.

VELARDO, J. T. (1958) Induction of pseudopregnancy in adult rats with Trilafon, a highly potent tranquillizer of low toxicity. Fert. Steril. 9, 60.

WALKER, S. M. \& MATrHEWs, J. I. (1949) Observations on the effects of prepartal and postpartal estrogen and progesterone treatment on lactation in the rat. Endocrinology, 44, 8.

Weller, C. P., Shani (Mishkinsky), J., Grvant, Y. \& Sulman, F. G. (1972) Dissociation between the mammotrophic and galactopoietic effects of perphenazine sulphoxide in the rat. Archs int. Pharmacodyn. Ther. 200, 405.

Wellings, S. R., DeOme, K. B. \& Pitelka, D. R. (1960) Electron microscopy of milk secretion in the mammary gland of the $\mathrm{C}^{3} \mathrm{H} / \mathrm{Crgl}$ mouse. 1. Cytomorphology of the prelactating and lactating gland. 7. natn. Cancer Inst. 25, 393.

Wellings, S. R. \& NANDI, S. (1968) Electron microscopy of induced secretion in mammary epithelial cells of hypophysectomized-ovariectomized-adrenalectomized $\mathrm{BALB} / \mathrm{cCrgl}$ mice. F. natn. Cancer Inst. 40, 1245.

Welings, S. R. \& Philp, J. R. (1964) The function of the Golgi apparatus in lactating cells of the BALB/cCrgl mouse. Z. Zellforsch. mikrosk. Anat. 61, 871. 